\title{
UPAYA KEPALA SEKOLAH UNTUK MENINGKATKAN KEMAMPUAN GURU DALAM PENGGUNAAN KOMPUTER MELALUI PENERAPAN METODE PEER TEACHING DI SMP 5 KOTA BOGOR
}

\author{
Warsadi ${ }^{\left.a^{*}\right)}$ \\ ${ }^{a)}$ SMP Negeri 5 Kota Bogor, Bogor, Indonesia \\ *) e-mail korespondensi: warsadi.smpn5Bgr@gmail.com
}

\begin{abstract}
Abstrak
Riwayat Artikel

diterima 11 Januari 2020

direvisi 23 Januari 2020

disetujui 12 Februari 2020

Penelitian ini dilatarbelakangi minimnya kemampuan guru dalam penggunaan komputer. Hal ini dapat mempengaruhi proses dan kualitas pembelajaran di kelas. Oleh karena itu seorang kepala sekolah harus berupaya untuk meningkatkan kompetensi dan kemampuan guru dalam penggunaan komputer, dalam hal ini upaya yang dilakukan adalah dengan menggunakan metode Peer Teaching. Penelitian ini bertujuan untuk (1) mengetahui penerapan metode peer teaching dapat meningkatkan kemampuan guru SMP Negeri 5 Bogor dalam menggunakan komputer. (2) menggambarkan proses peningkatan kemampuan guru SMP Negeri 5 Bogor dalam menggunakan komputer sesudah diterapkan metode peer teaching. (3) mengukur besarnya peningkatan kemampuan guru SMP Negeri 5 Bogor dalam menggunakan komputer sesudah diterapkan metode peer teaching. Hasil penelitian ini menunjukkan bahwa sebelum diterapkan metode peer teaching tentang penggunaan komputer di SMP Negeri 5 Bogor, dari 46 guru yang ada di SMP 5 Bogor terdapat 12 orang guru yang belum mampu menggunakan komputer. Kemudian dilakukan upaya untuk meningkatkan kemampuan guru dalam penggunaan komputer yaitu melalui penerapan metode peer teaching (tutor sebaya) Setelah metode peer teaching digunakan pada siklus I terjadi peningkatan kemampuan guru dalam penggunaan komputer yaitu didapat 9 orang guru mampu menggunakan komputer dan masih ada 3 orang guru yang masih belum mampu, kemudian dilakukan perbaikan pada siklus II sehingga terjadi peningkatan yang signifikan dengan adanya 6 orang guru yang menjadi mahir dalam penggunaan komputer dan 6 orang guru yang sudah mampu menggunakan komputer. Dari uraian di atas peneliti menyimpulkan bahwa penerapan metode peer teaching yang digunakan dapat meningkatkan kemampuan guru dalam menggunakan komputer, karena itu peneliti menyarankan agar penerapan metode peer teaching perlu disosialisasikan dan digunakan di sekolah-sekolah di lingkungan Dinas Pendidikan Kota Bogor.
\end{abstract}

Kata kunci: kemampuan guru; komputer; peer teaching.

\section{THE EFFORTS OF HEADMASTER TO IMPROVE TEACHERS 'ABILITY IN COMPUTER USE THROUGH THE APPLICATION OF THE PEER TEACHING METHOD IN JUNIOR HIGH SCHOOL (SMP NEGERI 5), BOGOR CITY}

\begin{abstract}
This research was motivated by the lack of teachers' ability to use computers. This can affect the process and quality of learning in the classroom. Therefore a school principal must strive to improve the competence and ability of teachers in using computers, in this case the effort made is to use the Peer Teaching method. This study aims to (1) determine that the application of the peer teaching method can improve the ability of teachers of SMP Negeri 5 Bogor in using computers. (2) describes the process of increasing the ability of teachers at SMP Negeri 5 Bogor in using computers after the peer teaching method was applied. (3) measuring the amount of improvement in the ability of teachers at SMP Negeri 5 Bogor in using computers after the peer teaching method was applied. The results of this study indicate that before the application of the peer teaching method on computer use at SMP Negeri 5 Bogor, of the 46 teachers in SMP 5 Bogor, there were 12 teachers who were not able to use computers. Then an effort was made to improve the teacher's ability to use computers, namely through the application of the peer teaching method. still unable, then improvements were made in cycle II so that there was a significant increase in the presence of 6 teachers who became proficient in using computers and 6 teachers who were able to use computers. From the above description, the researcher concludes that the application of the peer teaching method used can improve the ability of teachers to use computers, therefore the researcher suggests that the application of the peer teaching method needs to be socialized and used in schools in the Bogor City Education Office.
\end{abstract}

Keywords: teacher ability; computer; peer teaching 


\section{PENDAHULUAN}

Kemajuan teknologi komputer membuat aktivitas menjadi serba cepat serta menjadikan dunia seperti tanpa batas. Berbagai jenis informasi dapat diakses dengan cepat dan akurat. Gelombang perubahan yang mengguncangkan ini telah memaksa sektor pendidikan untuk memikirkan kembali segala sesuatu yang selama ini kita pahami tentang pembelajaran, pendidikan maupun persekolahan. Revolusi teknologi harus juga diimbangi dengan pembaharuan pendidikan, pengajaran dan persekolahan.

Dengan masuknya teknologi informasi khususnya komputer telah banyak merubah tatanan dan peran pendidikan. Sebagai contoh, dahulunya guru merupakan sumber informasi yang utama bagi peserta didik dengan hadirnya komputer melalui jaringan internet telah membuat guru bukanlah satu-satunya sumber informasi, tapi infomasi dapat diakses dari komputer melalui jaringan internetnya, proses belajar mengajar yang disampaikan secara klasikal dengan metode ceramah yang membosankan [1]. Tapi dengan hadirnya teknologi komputer menyebabkan pembelajaran dapat dilakukan secara individual dan menyenangkan. Masih banyak lagi hal yang mengalami perubahan mendasar dengan hadirnya teknologi komputer ini.

Peranan teknologi komputer pada aktivitas manusia pada saat ini memang begitu besar. Komputer telah menjadi fasilitator utama bagi kegiatan-kegiatan disemua sektor kehidupan termasuk dalam sektor pendidikan. Komputer telah memberikan andil besar terhadap perubahan-perubahan yang mendasar pada struktur, operasi, dan manajemen sistem pendidikan dan pembelajaran. Berkat teknologi komputer ini berbagai kemudahan dapat dirasakan dalam proses pembelajaran seperti persentasi mengajar, akses informasi (e-learning) dan pembuatan pembelajaran berbasis komputer [2]

Seorang guru mempunyai tugas sebagai pendidik, pengajar dan pelatih bagi para peserta didiknya, oleh karena itu guru dituntut untuk memiliki berbagai macam kemampuan. Diantara kemampuan itu adalah kemampuan mengembangkan diri secara profesional. Sehingga pada akhirnya guru dituntut untuk melihat dan menilai kinerjanya. Mengembangkan materi dan media pembelajaran yang bervariasi dan relevan dengan menggunakan kompuer serta harus mampu mengembangkan model-model pembelajaran yang sesuai dengan standar kompetensi mata pelajaran [3].

Guru merupakan salah satu pelaku yang sangat penting dalam dunia pendidikan. Tugasnya adalah melaksanakan pembelajaran sebagai upaya mewujudkan tujuan pendidikan nasional [4]. Oleh karena itu kepala sekolah dituntut untuk dapat melakukan Penelitian Tindakan Sekolah guna perbaikan proses pembelajaran yang telah dilakukan oleh guru di sekolah agar tujuan pembelajaran dapat berhasil sesuai dengan harapan. Proses belajar mengajar dapat berhasil apabila dilaksanakan dengan maksimal [5]. Pada proses belajar mengajar di sekolah terdapat keterkaitan antara guru, kurikulum serta sarana dan prasarana.

Kepala sekolah sebagai educator yaitu kepala sekolah bertugas untuk membimbing guru, tenaga kependidikan, peserta didik, mengikuti perkembangan iptek, dan memberi teladan yang baik [6]. Oleh karena itu upaya yang dapat dilakukan kepala sekolah dalam meningkatkan kinerja sebagai educator, khususnya dalam peningkatan kinerja guru dan prestasi belajar peserta didik adalah mengikutsertakan guru-guru dalam pendidikan lanjutan dengan cara mendorong para guru untuk memulai kreatif dan berprestasi [7].

Kepala sekolah sebagai manager yaitu mempunyai fungsi menyusun perencanaan, mengkoordinasikan kegiatan, melakukan pengawasan, melakukan evaluasi terhadap kegiatan, mengadakan rapat, mengambil keputusan, mengatur proses pembelajaran, mengatur administrasi, dan mengatur tata usaha, peserta didik, ketenagaan, sarana dan prasarana, keuangan [5]. Kepala sekolah sebagai manajer dituntut memiliki kesiapan untuk mengelola sekolah, kemampuan dan kemauan muncul manakala para pemimpin sekolah dapat membuka diri secara luas untuk menyerap sumber-sumber yang dapat mendorong perubahan manajerial [7]. Untuk melakukan peran dan fungsinya sebagai manajer, kepala sekolah harus memiliki strategi yang tepat untuk memberdayakan tenaga kependidikan melalui kerjasama, memberi kesempatan kepada para tenaga pendidikan untuk meningkatkan profesinya dan mendorong keterlibatan seluruh tenaga kependidikan yang menunjang program sekolah.

SMP Negeri 5 Bogor memiliki 46 tenaga pendidik (guru), antara lain 39 orang berstatus PNS dan 7 orang masih berstatus honorer. Pada saat observasi di kelas, sebagian guru tidak menggunakan media pembelajaran yang efektif seperti menggunakan komputer pada saat proses belajar mengajar berlangsung. Namun secara umum kemampuan guru dalam pengelolaan kelas cukup memadai namun metode dan media yang digunakan dalam kegiatan pembelajaran belum tepat dan monoton. Sehingga interaksi dan komunikasi yang dikembangkan dengan peserta didik masih satu arah. Akibat yang timbul dari proses pembelajaran tersebut adalah minat belajar peserta didik menjadi sangat rendah dan kurang memuaskan di karenakan tidak menarik dan menyenangkan bagi peserta didik.

Bagi seorang guru komputer merupakan salah satu perangkat yang teramat sangat penting, terlebih lagi dalam rangka mensukseskan program mengajarnya. Dalam hal penyusunan soal saja, guru dituntut untuk membuat soal sedemikian rupa yang dalam pembuatannya tentu membutuhkan alat, yaitu komputer. Memang sebenarnya ada alat lain yang bisa dipergunakan dalam hal penyusunan soal seperti dengan menulis tangan atau juga dengan mesin ketik. Tapi sekarang sudah zaman modern, tidak ada salahnya juga kita mengikuti perkembangan zaman dan mempergunakan fasilitas yang ada. Dengan mempergunakan komputer hasil yang didapat akan lebih 
baik dan berkualitas jika dibandingkan dengan cara yang konvensional.

Dalam bahasa Indonesia Peer Teaching lebih dikenal dengan istilah tutor sebaya. Salah satu ahli yang melakukan penelitian tentang ini adalah Dejnozken dan kopel dalam American Education Encyclopedia menjelasakan mengenai tutor sebaya, menurutnya tutor sebaya merupakan sebuah prosedur dalam proses pembelajaran antara satu siswa mengajar siswa lainnya [8]. Tipe pertama adalah pengajaran dan pembelajaran ditinjau dari usia yang sama. Tipe kedua adalah pengajar yang lebih tua usianya dari pembelajar. Tipe yang lain kadang dimunculkan pertukaran usia pengajar. Tutor berfungsi sebagi pelaksana mengajar, cara mengajarnya telah disiapkan secara khusus dan terperinci. Dalam pengguanaan metode pembelajaran ini tentunya memiliki kelebihan dan kekurangan, demikian juga halnya dengan peerteaching ini. Metode ini, setiap guru akan mendapat giliran tampil sebagai guru dalam kegiatan peer teaching dan guru yang lain berlaku sebagai peserta dan pengamat [9].

Kelebihan peer teaching (tutor sebaya) sebagai upaya untuk meningkatkan kemampuan guru dalam menggunakan komputer yaitu dalam penerapan tutor sebaya, guru dilatih untuk mandiri, dewasa, dan punya rasa setia kawan yang tinggi [10]. Metode pembelajaran tutor sebaya ini mempunyai tujuan penting dalam kelompok, dapat melatih tanggung jawab individu dan memberikan pengajaran kepada seseorang yang diajar untuk saling membantu satu sama lain dan saling mendorong untuk melakukan usaha yang maksimal.

Dengan menggunakan metode pembelajaran tutor sebaya dalam kelompok kecil, mempunyai fungsi antara lain membantu guru yang kurang mampu agar mudah memahami penggunaan komputer, guru yang kurang aktif menjadi aktif karena tidak malu lagi untuk bertanya dan mengeluarkan pendapat secara bebas. Dalam hal ini tutor maupun yang ditutori sama mendapatkan keuntungan. Bagi tutor akan mendapatkan pengalaman, sedangkan yang ditutori akan lebih mudah dalam menerima pemahaman [8].Pendampingan ini peran kepala sekolah hanya sebagai fasilitator atau pembimbing, artinya kepala sekolah hanya melakukan intervensi ketika benar-benar dibutuhkan guru dan memotivasi guru untuk aktif belajar memahami komputer [11].

Teknologi media komunikasi memang memberi kemudahan dalam hidup. Manusia tidak perlu lagi membuang waktu, biaya dan tenaga yang besar hanya untuk berkomunikasi dengan orang lain dimanapun mereka berada. Akan tetapi, setiap hal atau benda pasti memiliki nilai positif dan negatifnya. Dibalik semua keuntungan yang di dapat dari teknologi media komunikasi seperti komputer [2].

Guru dapat mengembangkan kompetensinya melalui belajar dari berbagai program pelatihan dari sekolah maupun dari luar sekolah. Dengan demikian diharapkan guru akan mampu bersikap profesional dalam proses pendidikan dan pengajaran di kelas. Karena itu, sekolah wajib menyediakan pelatihan atau pendampingan demi lahirnya guru-guru yang kompeten; sekolah wajib memiliki manajemen pengembangan kompetensi guru.

Kemampuan guru dalam menggunakan komputer pada pembelajaran yaitu kemampuan seorang guru menggunakan suatu alat untuk menggambarkan orang yang perkerjaannya melakukan pengetikan atau perhitungan aritmatika, dengan alat bantu yang dinamakan komputer.

Pendampingan dengan metode peer teaching (tutor sebaya) merupakan metode yang dilakukan untuk meningkatkan penguasaan ketrampilan komputer dikategorikan dalam pendukung proses pembelajaran, pembuatan media pembelajaran, pengolahan dokumen, pengolahan data administrasi, dan pengeksplorasian internet.

Semakin baik peningkatan kemampuan guru dalam menggunakan komputer, maka akan baik pula proses pembelajaran guru kepada peserta didik, sehingga diduga ada peningkatan kemampuan guru dalam menggunakan komputer di SMP Negeri 5 Bogor.

Berdasarkan kenyataan hasil pengamatan dan pengisian angket skala kemampuan penggunaan komputer terhadap 46 orang guru di SMP Negeri 5 Bogor, diperoleh hasil bahwa 12 orang guru masih belum mampu dalam menggunakan komputer, 28 orang guru mampu dalam menggunakan komputer dan 6 orang guru dikategorikan sangat mampu/mahir dalam penggunaan komputer.

Berangkat dari permasalahan-permasalahan di atas, maka peneliti mencoba menerapkan metode untuk membantu meningkatkan kemampuan guru dalam penggunaan komputer yaitu melalui metode peer teaching dengan subjek penelitian sebanyak 12 orang guru yang belum mampu menggunakan komputer. Pendampingan yang dilakukan dengan membentuk kelompok-kelompok kecil yang dipandu oleh rekan guru yang dianggap sudah sangat mampu/mahir dalam penggunaan komputer. Melalui metode peer teaching, guru akan dapat berdiskusi, bertukar pendapat tanpa ada rasa canggung.

\section{METODE PENELITIAN}

Penelitian Tindakan Sekolah (PTS) ini dengan waktu pelaksanaannya 1 Semester, bulan Juli - Desember 2018. Lokasi di SMP Negeri 5 Kota Bogor. Penelitian Tindakan Sekolah dilakukan pada guru yang ada di SMP Negeri 5 Bogor Kecamatan Tanah Sareal Kota Bogor. Jumlah guru yang ada di SMP Negeri 5 Bogor adalah 46 orang. Yang terdiri dari 11 orang laki-laki dan 35 orang perempuan. Prosedur penelitian tindakan sekolah ini terdiri atas dua siklus, tiap siklus yang diteliti disesuaikan dengan perubahan yang dicapai, untuk lebih jelas dan tahapan siklus sebagai berikut: 1) Perencanaan Tindakan, 2) Pelaksanaan Tindakan, 3) Observasi, dan 4) Evaluasi dan refleksi. Seperti hal yang telah didesain dalam faktor-faktor yang diselidiki. Metode pengumpulan data merupakan langkah yang paling strategis dalam penelitian, karena tujuan utama dari penelitian adalah mendapatkan data. Pengumpulan data dapat dilakukan dengan dalam berbagai setting, berbagai sumber, dan 
berbagai cara. Langkah-langkah validasi data yang digunakan dalam penelitian tindakan bimbingan dan konseling ini adalah Verifikasi Data, Mengklarifikasikan dan Mentabulasikan Data, Menghitung Persentase, Menganalisis Hasil, Penyimpulan dan Pemaknaan. Penelitian tindakan sekolah (PTS) sebenarnya mengadop prinsip prinsip yang terdapat pada penelitian tindakan atau action research. Yaitu suatu riset yang tidak saja bermaksud mengidentifikasi sejumlah masalah pada berbagai macam kegiatan, melainkan sekaligus merumuskan alternatif pemecahan, menerapkan alternatif pemecahan yang sudah dirumuskan sebagai suatu tindakan, melakukan evaluasi terhadap tindakan dan memberikan umpan balik guna merumuskan tindakan berikutnya. Kegiatan merumuskan alternatif tindakan, melakukan tindakan, evaluasi tindakan dan umpan balik dilakukan secara berulang dalam beberapa siklus. Hopkins dan Mc Taggart menyusun bagan yang dapat memperjelas prosedur penelitian tindakan sebagaimana pada gambar 1. Hopkins dan Mc Taggart menyusun bagan yang dapat memperjelas prosedur penelitian tindakan sebagaimana pada

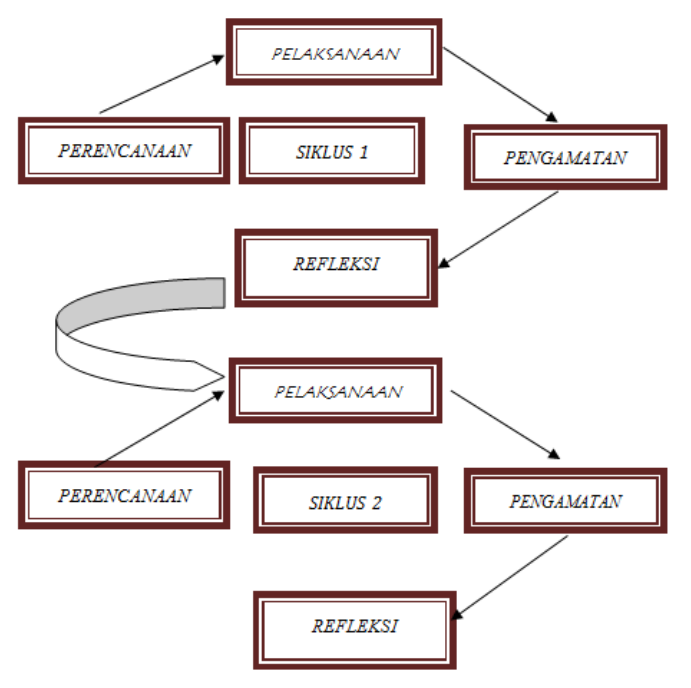

Gambar 1. Alur Pelaksanaan Tindakan dalam Penelitian Tindakan Sekolah Berdasarkan Model John Elliot

\section{HASIL DAN PEMBAHASAN}

Dalam melaksanakan metode Peer Teaching, langkah awal yang dilakukan adalah membuat jadwal kegiatan dengan guru-guru yang akan mengikuti Peer Teaching atau tutor sebaya. Berdasarkan penyebaran data angket skala kemampuan penggunaan komputer diperoleh 12 orang guru yang dijadikan subjek penelitian karena belum mampu dalam menggunakan komputer. 12 orang guru masih belum mampu menggunakan komputer, hal ini dapat dilihat dari skor yang didapat yaitu <40. Masih rendahnya skor kemampuan guru yang dicapai, menunjukkan bahwa guru belum mampu menggunakan komputer. Berdasarkan fakta seperti itu, maka peneliti ingin menerapkan metode Peer teaching yang dapat mengaktifkan guru serta menarik minat guru untuk belajar menggunakan komputer. Setelah disepakati akan dilaksanakan metode Peer Teaching unuk meningkatkan kemampuan guru dalam menggunakan komputer, maka kegiatan selanjutnya adalah mempersiapkan materi tentang penguasaan keterampilan komputer terhadap program Microsoft Office.

Hasil pengamatan observer terhadap kepala sekolah adalah (20\%) kepala sekolah masih kurang jelas dalam pembagian kelompok dan tidak menutup kegiatan metode Peer Teaching. Sedangkan (40\%) sekolah cukup baik dalam teknik penyampaian materi, memotivasi, teknik bertanya, dan membimbing peserta didik diskusi kelompok. Sedangkan $(40 \%)$ kepala sekolah baik dalam memberikan materi terutama, teknik pengelolaan kelas, kejelasan suara dan pemberian umpan balik. Selain dilakukan pengamatan terhadap aktivitas kepala sekolah, juga dilakukan pengamatan terhadap aktivitas guru. Digambarkan maka pada gambar 2 .

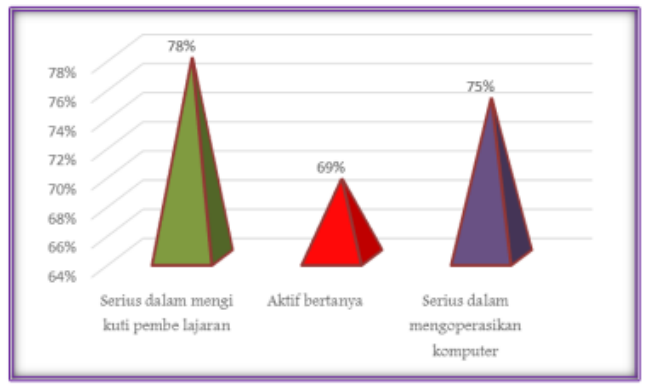

Gambar 2. Data Aktivitas Guru Pada Siklus I

Refleksi siklus I pertemuan kedua dilakukan bersama dengan observer. Kegiatan ini bertujuan untuk mencari dan menemukan indikator-indikator yang telah tercapai dan yang belum tercapai dalam pembelajaran pertemuan kedua. Adapun caranya adalah dengan membandingkan kemampuan individual maupun klasikal yang ditandai dengan ketercapaian rata-rata kemampuan yang telah ditetapkan sebelumnya. Selanjutnya, peneliti mencari penyebab dan solusi untuk mengatasinya. Hasil analisis terhadap kemampuan penggunaan komputer pada guru adalah 9 orang guru sudah mampu dalam menggunakan komputer. Terjadi peningkatan dari pra siklus sebanyak 12 orang yang belum mampu menggunakan komputer dan pada siklus I hanya tersisa 3 orang yang belum mampu menggunakan komputer. Hasil analisis terhadap rata-rata kemampuan penggunaan komputer terjadi kenaikan dari kondisi pra siklus sebesar 33,08 menjadi 48,84. Setelah melaksanakan pengamatan terhadap pelaksanaan metode Peer Teaching kemudian diadakan refleksi dari tindakan yang telah dilakukan, pada tindakan siklus I didapat hasil bahwa kepala sekolah harus lebih jelas dalam membagi tugas kelompok dan kemampuan menutup kegiatan metode Peer Teaching harus lebih baik. 
Sekalipun telah terjadi peningkatan terhadap proses dan kemampuan guru dalam menggunakan komputer pada siklus I, tetapi tindakan perbaikan masih dilanjutkan ke siklus berikutnya, karena target belum tercapai. Di dalam indikator keberhasilan ditetapkan bahwa aktivitas guru yang harus dicapai adalah $80 \%$ guru aktif dalam proses pembelajaran sedangkan hasil dari siklus I baru $74 \%$. Dengan demikian penelitian ini dilanjutkan ke siklus berikutnya.

Langkah-langkah kegiatan tindakan pada siklus II adalah sama dengan langkah-langkah pada siklus I, namun yang membedakan pada siklus II guru lebih aktif dalam pembelajaran. Selain dilakukan pengamatan terhadap aktivitas kepala sekolah, juga dilakukan pengamatan terhadap aktivitas guru. Data aktivitas guru dalam mengikuti Peer Teaching pada siklus II dipersentasekan dalam bentuk grafik, dilihat pada gambar 3 .

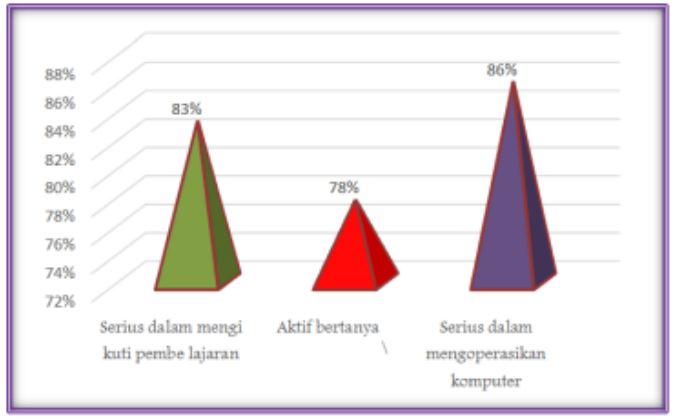

\section{Grafik 3. Data Aktivitas Guru Pada Siklus II}

Terlihat adanya peningkatan rata-rata kemampuan guru naik dari pra siklus hanya 48,84 menjadi 60,67 pada siklus II. Guru yang mahir menggunakan komputer menjadi 6 orang, yang mampu 6 orang dan tidak ada guru yang belum mampu menggunakan computer. Refleksi siklus II pertemuan kedua dilakukan bersama dengan observer. Kegiatan ini bertujuan untuk mencari dan menemukan indikator-indikator yang telah tercapai dan yang belum tercapai dalam pembelajaran pertemuan kedua. Adapun caranya adalah dengan membandingkan kemampuan individual maupun klasikal yang ditandai dengan ketercapaian rata-rata kemampuan yang telah ditetapkan sebelumnya. Selanjutnya, peneliti mencari penyebab dan solusi untuk mengatasinya.

Hasil analisis terhadap kemampuan penggunaan komputer pada guru adalah 6 orang guru sudah mahir dalam menggunakan komputer, 6 orang guru mampu menggunakan komputer dan tidak ada guru yang belum mampu menggunakan komputer. Setelah melaksanakan pengamatan terhadap pelaksanaan metode Peer Teaching kemudian diadakan refleksi dari tindakan yang telah dilakukan, pada tindakan siklus II didapat hasil bahwa kepala sekolah sudah membagi tugas kelompok dengan baik dan teknik menutup kegiatan yang dilakukan Kepala Sekolah sudah lebih baik. Dengan demikian telah terjadi peningkatan terhadap proses pembelajaran dengan metode Peer Teaching pada siklus II, sehingga tindakan perbaikan pembelajaran tidak perlu dilanjutkan ke siklus berikutnya, karena target sudah tercapai.

Di dalam indikator keberhasilan diketahui bahwa rata-rata kemampuan penggunaan komputer terjadi kenaikan dari kondisi pra siklus sebesar 48,84 menjadi 60,67 pada siklus II. Hal ini sudah melebihi dari target yang ditentukan yaitu sebesar 50,00. Begitu juga rata-rata aktivitas guru telah mencapai $82 \%$ dari target yang ditetapkan sebesar $80 \%$ Dengan demikian penelitian ini tidak perlu dilanjutkan ke siklus berikutnya. Diterapkan metode Peer Teaching, kemampuan guru dalam penggunaan komputer mengalami peningkatan. Nilai ratarata pra siklus 33,08 meningkat menjadi 48,83 pada siklus I, dan meningkat lagi menjadi 60,67 pada siklus II. Hal ini sudah melebihi dari target yang ditentukan yaitu sebesar 50,00 . Peningkatan kemampuan guru tersebut menunjukkan bahwa tingkat pemahaman guru dalam menggunakan komputer semakin meningkat. Dengan demikian penelitian dihentikan sampai siklus II karena telah mencapai target tersebut. Ketertarikan guru terhadap pembelajaran tentang komputer dengan penggunaan metode Peer Teaching (CIRC) merupakan salah satu faktor yang mempengaruhi peningkatan kemampuan guru.

Keaktifan guru terhadap pembelajaran dengan menggunakan metode Peer Teaching juga dapat mempengaruhi kemampuan guru dalam penggunaan komputer. Berdasarkan hasil pengamatan dari siklus I sampai siklus II ternyata keaktifan guru juga mengalami peningkatan. Keaktifan guru dalam penggunaan metode Peer Teaching yaitu keseriusan dalam mengikuti pembelajaran, keaktifan dalam bertanya dan keseriusan dalam mengoperasikan computer. Untuk aspek keseriusan guru dalam mengikuti pembelajaran terjadi peningkatan persentase jumlah guru dari siklus I sampai siklus II, yaitu 78\% pada siklus I menjadi $83 \%$ pada siklus II. Keaktifan guru dalam bertanya juga mengalami peningkatan yaitu 69\% pada siklus I, meningkat menjadi $78 \%$ pada siklus II. Dan keseriusan dalam mengoperasikan komputer telah mencapai $86 \%$ untuk siklus kedua, ini menunjukan bahwa guru telah aktif dan serius dalam pembelajaran komputer.

Adanya peningkatan ketertarikan dan keaktifan guru dalam proses pembelajaran diduga karena guru memperoleh hal-hal baru yang menarik dan tidak menjenuhkan karena dalam proses pembelajaran dengan menggunakan metode Peer Teaching tidak ada kecanggungan atau keengganan bagi guru dalam bertanya karena pendampingan pembelajaran dilakukan oleh rekan sejawat. Sebelum melaksanakan kegiatan belajar mengajar, kepala sekolah terlebih dahulu menjelaskan hal-hal yang harus dikerjakan oleh guru, yaitu guru diberi tugas untuk mencari informasi tentang materi yang akan dibahas baik melalui buku, internet, maupun literatur lain. Kegiatan selanjutnya adalah guru mempraktekan teori yang sudah didapat dengan didampingi oleh rekan sejawat yang lebih mahir sebagai tutornya. Untuk lebih memotivasi guru, kepala sekolah memberikan penghargaan atas kemampuan yang telah dicapai oleh guru dalam peningkatan kemampuannya menggunakan komputer. Pada kondisi 
awal proses pembelajaran berlangsung, terlihat guru masih canggung dan kurang antusias dalam mengikuti proses pembelajaran karena berbagai faktor, diantaranya disebabkan oleh ketidaktahuannya dalam pengoperasian komputer.

Setelah dilakukan tindakan perbaikan di siklus I dan dilaksanakan pengamatan terhadap pelaksanaan pembelajaran, terjadi peningkatan yaitu kepala sekolah berhasil lebih meningkatkan minat guru yaitu memotivasi guru selama proses pembelajaran berlangsung. Namun kepala sekolah masih perlu meningkatkan kemampuannya dalam pembagian tugas kelompok dan teknik menutup kegiatan pembelajaran Peer Teaching yang lebih baik. Pada siklus II, proses pembelajaran lebih utuh yaitu guru lebih aktif dan kreatif dalam mengikuti proses pembelajaran, motivasi guru untuk mengikuti proses pembelajaran dengan penggunaan metode Peer teaching meningkat.. Hal-hal tersebut yang menyebabkan proses pembelajaran bisa mencapai hasil yang optimal Berdasarkan hasil penelitian pada siklus II maka hasil refleksi selama kegiatan penelitian yang dimulai dari persiapan sampai pada pelaksanaan dianggap sudah berhasil, hal ini berdasarkan tingkat kemampuan guru yang cukup baik.

\section{KESIMPULAN}

Setelah dilakukan tindakan penelitian maka dapat disimpulkan bahwa kemampuan guru dalam menggunakan komputer melalui penggunaan metode Peer Teaching ternyata dapat meningkatkan minat, antusias, konsentrasi, dan keaktifan guru dalam proses pembelajaran. Selain itu juga terjadi peningkatan kemampuan guru dalam menggunakan komputer berupa naiknya nilai rata-rata dan naiknya kemampuan secara individu maupun secara klasikal pada guru di SMP Negeri 5 Bogor pada tahun pelajaran 2018/2019. Dengan demikian maka berdasarkan paparan penelitian di atas maka disimpulkan:

Penggunaan metode Peer Teaching dapat meningkatkan kemampuan guru dalam penggunaan komputer di SMP Negeri 5 Bogor tahun pelajaran 2018/2019

Penggunaan metode Peer Teaching dalam pembelajaran membuat guru tidak bosan dan jenuh sebaliknya merasa bersemangat sehingga aktivitas belajar mereka pun meningkat. Hal ini terbukti pada aspek keseriusan guru dalam mengikuti pembelajaran terjadi peningkatan persentase jumlah guru dari siklus I sampai siklus II, yaitu $78 \%$ pada siklus I menjadi $83 \%$ pada siklus II. Aspek keaktifan guru dalam bertanya juga mengalami peningkatan yaitu $69 \%$ pada siklus I, meningkat menjadi $78 \%$ pada siklus II. Dan keseriusan dalam mengoperasikan komputer telah mencapai $86 \%$ untuk siklus kedua, ini menunjukan bahwa guru telah aktif dalam pembelajaran dan. Hal tersebut berpengaruh terhadap kemampuan yang dicapai oleh guru.

Besar peningkatan kemampuan yang dapat dicapai melalui penggunaan metode Peer Teaching pada penggunaan komputer adalah pada kondisi awal mempunyai nilai rata-rata yang dicapai hanya 33,08. Pada saat metode Peer Teaching dilakukan rata-rata kemampuan guru meningkat menjadi 48,83 pada siklus I dan 60,67 pada siklus II.

Jumlah guru yang mampu dalam penggunaan komputepun meningkat, pada waktu pra siklus 12 orang guru belum mampu menggunakan komputer setelah menggunakan metode Peer Teaching meningkat pada siklus I menjadi 3 orang guru yang belum mampu dan 9 orang yang sudah mampu menggunakan computer. Pada siklus II terjadi peningkatan yang signifikan yaitu sudah tidak ada lagi guru yang belum mampu menggunakan computer, tetapi sebaliknya ada 6 orang guru yang menjadi mahir dan 6 orang guru yang sudah mampu menggunakan komputer.

\section{REFERENSI}

[1] Muslihuddin 2010, Kiat Sukses Melakukan Penelitian Tindakan Kelas dan Sekolah, Bandung, Rizqi Press.

[2] Wimartono. 2016. Analisis Pengaruh Penggunaan Teknologi Informasi Terhadap Profesi Guru (Studi Kasus: Kab. Kebumen). Citec Journal, 3(1), 74-88.

[3] Nana Sudjana. 2009. Dasar-dasar Proses Belajar Mengajar. Bandung: Sinar Baru Algensinda

[4] N. Karmila and Y. Suchyadi, Supervisi Pendidikan Di Sekolah Alam Bogor, J. Pendidik. dan Pengajaran Guru Sekol. Dasar, vol. 03, pp. 31-33, 2020.

[5] Y. Suchyadi, N. Karmila, and N. Safitri, Kepuasan Kerja Guru Ditinjau Dari Peran Supervisi Kepala Sekolah Dasar Negeri Di Kecamatan Bogor Utara, JPPGuseda | J. Pendidik. Pengajaran Guru Sekol. Dasar, vol. 2, no. 2, pp. 91-94, Nov. 2019.

[6] Y. Suchyadi et al., Increasing Personality Competence Of Primary School Teachers, Through Education Supervision Activities In Bogor City," J. Community Engagem., vol. 01, no. 01, 2019.

[7] Ngalim Purwanto. 2002, Administrasi Dan Supervisi Pendidikan, Bandung: PT. Remaja Rosdakarya, hal. 65

[8] Herianto 2010. Efektivitas Model Pembelajaran Tutor Sebaya terhadap Hasil Belajar Microsoft Excel Di Kelas Viii Smp Dua Mei Banjaran. Bandung: Universitas Pendidikan Indonesia

[9] E.Mulyasa, Menjadi Kepala Sekolah Profesional, Bandung : PT Remaja Rosdakarya, 2007, hal. 98122

[10] Febianti, Yopi Nisa. 2014. "Peer Teaching (Tutor Sebaya) Sebagai Metode Pembelajaran Untuk Melatih Siswa Mengajar, Jurnal Edunomic". 2 (2)

[11] Soewadji Lazaruth, Kepala Sekolah dan Tanggung Jawabnya, Yogyakarta: Kanisius, 1994, cet. VI, hal. 20 